Teknokultura. Revista de Cultura Digital y Movimientos Sociales

ISSNe: $1549-2230$

http://dx.doi.org/10.5209/tekn.66912

\title{
Migrants and Patria. The imagined community of the radical left in Spain
}

Josep Lobera ${ }^{1}$

Recibido: 8 de diciembre 2019 / Aceptado: 7 de enero 2020 Open peer reviews

\begin{abstract}
The emergence of inclusive populist parties disputes the social construction of the 'people' to the exclusive populism, recently generating new academic debates. Do the new radical left parties have a nationalist character? Are populism and nationalism two inseparable dimensions? Drawing on an original dataset in Spain, this article shows that Podemos' supporters are significantly less nationalist, expressing more open attitudes towards cultural diversity and immigration, and lower levels of Spanishness than voters from other parties. Arguably, Podemos operates as an antagonistic political option to the traditional positions of the populist radical right (PRR), building an inclusive imagined community around a type of constitutional patriotism or republican populism. These findings contribute to the scholar debate on the relationship of nationalism and populism, bringing to discussion the core values of the supporters of a populist party as a complementary element to its categorization.
\end{abstract}

Keywords: assimilationism; constitutional patriotism; nationalism; populism; preferentialism.

\section{[es] Inmigrantes y Patria. La comunidad imaginada de la izquierda radical en España}

Resumen. El surgimiento de partidos populistas inclusivos disputa la construcción social del "pueblo" a los populismos excluyentes, generando recientemente nuevos debates académicos. ¿Tienen los nuevos partidos de izquierda radicales un carácter nacionalista? ¿Son el populismo y el nacionalismo dos dimensiones inseparables? Basándose en un conjunto de datos primarios en España, este artículo muestra que los votantes de Podemos son significativamente menos nacionalistas, expresando actitudes más abiertas hacia la diversidad cultural y la inmigración, así como niveles más bajos de españolidad que los votantes de otros partidos. Podríamos decir que Podemos opera como una opción política antagónica a las posiciones tradicionales de la derecha populista radical, construyendo en ese antagonismo una comunidad imaginaria inclusiva en torno un tipo de patriotismo constitucional o populismo republicano. Estos hallazgos contribuyen al debate académico sobre la relación del nacionalismo y el populismo, trayendo a discusión los valores centrales de los partidarios de un partido populista como un elemento complementario a su categorización.

Palabras clave: asimilacionismo; nacionalismo; populismo; patriotismo constitucional; preferencialismo.

Summary. 1. Introduction. 2. Theoretical framework. 3. Case selection rationale and method. 4. Findings. 5. Discussion. 6. Conclusions. 7. Acknowledgments. 8. References. 9. Appendices.

Cómo citar: Lobera, J. (2020). Migrants and Patria. The imagined community of the radical left in Spain. Teknokultura. Revista de Cultura Digital y Movimientos Sociales, 17(1), 59-68.

\section{Introduction}

We are living in times of strong feelings about the position of migration in relation to the nation. Fear and uncertainty drive some people towards a political vote rejecting migrants and population movements. Against the exclusionary politics emerging in European populist movements - such as the Spanish Vox, the French Front National (National Front), the Belgian Vlaams Belang (Flemish Interest), and the Austrian Freiheitliche Partei Österreichs (Freedom Party of Austria)- the emergence of inclusive social protest movements has allowed for the dispute about the social construction of the 'people' (Žižek, 2016; Mudde \& Rovira-Kaltwasser, 2013; Lobera \& Parejo, 2019).
Public support of the populist radical right (PRR) in Europe has increased since the late 1980s. Among the generally accepted causes of this increase are the growing distrust of political institutions, as well as the reaction against the changes generated by globalization, both economic (Betz, 1993; Swank \& Betz, 2003) and cultural (Inglehart \& Norris, 2016). There is, however, a lack of evidence on the link between the electoral support for inclusive populist parties, such as Podemos or Syriza, and their new conceptions of the nation and citizenship.

The new conceptions of the nation come into direct antagonistic competition with the ethnic logic of the nation exposed in the narrative of the PRR. Inclusive left-wing parties typically "emphasize 
egalitarianism and inclusivity rather than the openly exclusivist anti-immigrant or anti-foreigner concerns of right-populism (i.e. its concern is the demos not the ethnos)" (March, 2012, p. 122). To identify the voting factors for Podemos, we will test the common hypotheses of voting for far-right parties to see if they are significant in an opposite direction or if, on the contrary, they are not differentiating the vote for Podemos.

This article provides evidence on the key political values and attitudes to analyze the level of nationalism and the type of populism among the voters of Podemos. This study concludes that, in the case of Podemos, populism and nationalism are manifested in separate and even opposite dimensions, at least in the most common conceptualization of nationalism based on a "natural" conception of the nation. I argue that terms of constitutional patriotism or republican populism might be better fits for the case of Podemos's discourse, than the category of populist nationalism. A second contribution of this article is focused on perspective. Instead of the analysis of the elites' discourse or an analysis of strategy, I propose the analysis of voter values as a complementary element to discuss some of the previous analyzes.

\section{Theoretical framework}

The debate is vibrant. Are the new radical left parties nationalist? The scholarly analysis on two types of populisms (e.g. Mudde \& Rovira-Kaltwasser, 2013), one exclusive and nationalist on the right (such as Vox, Front National, UKIP), and another inclusive on the left (such as Podemos and Syriza), has led to a broader conceptual analysis of the relationship of populist and nationalist movements, also on the left. Are populism and nationalism two inseparable dimensions?

As Custodi and Caiani (2019) point out, both lines of reasoning are present in the literature. For some, nationalism and populism are two intersecting phenomena that are not analytically distinct (Brubaker, 2019). This position appeared implicitly in the large scholarship on Europe's populist radical right (PRR), where the two terms are often combined, and xenophobic nationalism becomes a 'primary connotation' of populism itself (Brubaker 2019, p. 2). In the recent scholarly debate, Brubaker is hesitant to accept a simplified, one-dimensional concept of populism. In his opinion, populism cannot be understood solely by vertical claimmaking along an up-down axis, since the invocation of the populism-typical 'the people' occurs along lines of both vertical and horizontal exclusions.

On the other hand, De Cleen and Stavrakakis $(2017 ; 2020)$ argue that nationalism and populism are significantly different and analytically separate manifestations. Even if both refer to 'the people', populism operates on an upward axis ('people as underdog'), while nationalism operates on a distinct inward axis ('people as nation') (De Cleen et al., 2019). Although the two axes may co-exist, one always prevails, relegating the other to the periphery of the actor's discourse. Consequently, right-wing populist actors are reported as primarily nationalist, whereas left-wing populist actors are reported as primarily populist, although this remains subject to further empirical analysis (Stavrakakis et al., 2017).

Additionally, there is also a discussion about a more adequate approach to analyze populist parties, particularly between approach based on the analysis of their ideational dimension (e.g., Mudde and Rovira Kaltwasser, 2017) and another based on their strategies (e.g, De Cleen, 2017; De Cleen et al., 2019; Custodi and Caiani, 2019). The main criticism of the ideational analysis is the risk "to hinder the full accounting for outcomes that are dependent in part on agency and action" (Barr, 2018, p. 53). On the other hand, the strategy-centered analysis may be affected by the difficulty of interpreting the ideological discourses in the symbolic-cultural context of the voters themselves, to whom the populist mobilization discourse is addressed.

Thus, the research question that leads this study is: are the voting bases of all populist parties nationalist? Specifically, I will analyze a case on which several studies have been conducted in recent years, the case of Podemos in Spain. To address this question, I review the main theories that explain the vote to nationalist populist parties to establish hypotheses about our case of study. The starting hypothesis is that, in the case of Podemos, populism is not associated with a nationalist mobilization. From this, the specific hypotheses on the voters of Podemos will arise.

Competition is a widespread approach of explaining the vote for PRR parties. Anchored in the more classical bases of the social sciences, a common assumption is that individuals pursue their own interest in the formation of their political opinions (Key, 1961; Campbell et al., 1960; Malchow-Møller et al., 2008). From this point of view, competition in the labor market or for public resources are key factors in the formation of attitudes. The far-right parties frequently frame hostility towards immigrants in economic terms, arguing that "immigrants not only burden social services with new expenditures, but they also take away scarce jobs from the native unemployed" (Betz, 1993, p. 416). Thus, we expect:

H1: a higher vote for Podemos among those less exposed to negative effects of globalization on work and employment: those with college education and higher household income.

H2: a lower vote for Podemos among those believing that Public Health is negatively affected by migrants.

In this vein, another common narrative in the PRR is preferentialism (De Orellana and Michelsen, 2019). Particularly, these parties oppose ethnic versus civic acquisition rules, including normatively overinclusion of co-ethnics and exclusion of individuals who do not belong to the national majority (Pogonyi, 2017). The principle of national preference is the rule 
for the set of measures proposed by far-right parties since their beginnings, like the Front National:

We demand (...) the suppression of all legislation and instructions tending to establish legal equality between French people and immigrants and we demand the final but gradual return of the immigrants to their countries of origin, with the exception of immediate expulsion for those whose aggressive behavior, permanent hatred and illegal actions are unworthy of French hospitality (Taguieff, 1989, p. 48).

Thus, we hypothesize:

H3: a lower vote for Podemos among those expressing preferentialist values.

Additionally, gender can influence partisan positions (Duverger, 1955; Inglehart and Norris, 2000). In the case of PRR support, there is evidence that points to a "populist radical right gender gap" (Campbell \& Erzeel, 2018, p. 96). One of the most consistent results in research of the PRR is that these parties tend to receive a disproportionate share of their support from men (Betz, 1993; Kitschelt, 1997; Norris, 2005). A gender gap in the populist radical left parties is also identified in the same direction, but it is considerably smaller than it was for the PRR (Spierings \& Zaslove, 2017). Thus, we expect the following hypothesis:

H4: a lower vote for Podemos among women than men.

Cultural theories are also a common explanation for the PRR vote. Drawing on surveys conducted in 31 countries, Inglehart and Norris (2016) argued that an important structural factor is a reactionary cultural movement (cultural backlash), especially in older generations, white men, and less qualified, previously dominant sectors, and that they resist losing its status in the face of the advancement of cultural diversity and the cosmopolitan values of open societies and globalization. Those groups would be particularly vulnerable to the call of right-wing populists.

The analytical distinction between socioeconomic factors and the artificial cultural reaction does not imply opposition. As Inglehart and Norris (2016, p. 3) point out, structural changes in the labor force and social trends in globalized markets may raise economic insecurity, and this, to in turn, it may stimulate a negative reaction among traditionalists towards cultural changes. In short, both dynamics and their interaction are necessary to explain the growing social unrest and citizen disaffection towards democracy and traditional parties (Sanahuja, 2017). Thus, we hypothesize:

H5: a lower vote to Podemos among those expressing assimilationist values.

On the other hand, hostility toward refugees have often been present in the political discourses of the
PRR (Wodak et al., 2013; Betz, 2017). Thus, we hypothesize:

H6: a lower vote for Podemos among those expressing anti-refugees attitudes.

Finally, speeches about the nation are a central message in the PRR. In the particular case of Spain, the concept of nation and national sentiment have been strongly influenced by recent history, particularly by Franco's nationalist dictatorship between 1939 and 1975. That is why we expect the feeling of Spanishness to be less present in the voters of the radical leftist party. Thus, we hypothesize:

H7: a lower vote for Podemos among those expressing higher levels of feeling of belonging to Spain.

\section{Case selection rationale and method}

The case of superdiverse areas in Spain is analytically useful for several reasons. First, Spain provides a context of deep changes in the political party system (Lobera, 2015) as well as in the influx of immigration, after an extraordinary "immigration boom" that brought the share of the foreign-born from near $4 \%$ of the total population to around $14 \%$ in less than a decade (Arango, 2018, p. 510). Secondly, superdiverse areas are more sensitive to exclusionary right-wing discourses, since a greater proportion of their population expresses xenophobic views than in non-superdiverse areas (Giménez et al., 2015). Thirdly, the severe financial and economic crisis has greatly impacted Spain since 2008, boosting unemployment from $8 \%$ to $27 \%$, exceeding $50 \%$ among immigrants and young people, and resulting in a reversal of migration trends.

I use data collected from 7,976 face-to-face structured interviews $(1,123$ of which are supporters of Podemos) carried out from October $2^{\text {nd }}$ to $17^{\text {th }}, 2017$, on native people who were 18 years of age or older and lived in 24 highly-diverse territories in Spain (see Appendix 1). The general characteristics of superdiversity identified by Vertovec $(2006,2007)$ in certain contexts in Britain appear in a similar fashion in these territories. On average, $29.9 \%$ of the population of those territories is foreign. Foreign nationalities with the greatest presence are Moroccans (15.3\%), Romanians (10.1\%), Ecuadorians (7.3\%), and Pakistanis (6.5\%). Additionally, about 5\% of Spaniards living in these territories self-identify as Roma.

The dependent variable is built as a dummy variable, $1=$ vote or preference for Podemos $(15 \%$; $\mathrm{n}=1,123) ; 0=$ don't vote or preference for Podemos $(85 \% ; n=6,376)$. As a first step of the analysis, we selected the following independent variables of sociodemographic character: gender, age, level of education, and household income level, as well as an indicator of feeling of belonging to Spain. In the second regression model, we incorporate 
all the controls described and used in the previous section (competition and cultural variables) to isolate the effect that other alternative explanatory factors could have on our dependent variables. The description of the independent variables is presented in Appendices 2 and 3.

\section{Findings}

The following table shows the results of the binary logistic regression model predicting the vote for Podemos (table $1)$. This table displays that the main variables tested show a significant effect on the dependent variable.

Table 1. Logit on Podemos' support. Source: our own production.

\begin{tabular}{|l|c|c|c|c|c|c|}
\hline & \multicolumn{3}{|c|}{ Model 1 } & \multicolumn{3}{c|}{ Model 2 } \\
\hline & B & S.E. & Sig. & B & S.E. & Sig. \\
\hline Gender (1=women) & -0.192 & 0.074 & 0.010 & -0.217 & 0.076 & 0.005 \\
\hline Age & -0.014 & 0.002 & 0.000 & -0.009 & 0.002 & 0.000 \\
\hline Education level & 0.317 & 0.031 & 0.000 & 0.210 & 0.032 & 0.000 \\
\hline Household income level & 0.054 & 0.039 & 0.162 & 0.010 & 0.040 & 0.802 \\
\hline Feeling Spaniard & -0.273 & 0.040 & 0.000 & -0.184 & 0.042 & 0.000 \\
\hline $\begin{array}{l}\text { Public Health negatively affected by migrants: } \\
\text { Strongly or somewhat agrees (ref.) }\end{array}$ & & & & & & 0.000 \\
\hline \multicolumn{1}{|c|}{ Somewhat disagrees } & & & & 0.308 & 0.100 & 0.002 \\
\hline \multicolumn{1}{|c|}{ Strongly disagrees } & & & & 0.776 & 0.099 & 0.000 \\
\hline Preferentialism & & & & -0.458 & 0.086 & 0.000 \\
\hline Refugees not welcome & & & & -0.273 & 0.121 & 0.024 \\
\hline Assimilationism & & & & & & \\
\hline Constant & -3.032 & 0.283 & 0.000 & -1.542 & 0.339 & 0.000 \\
\hline Nagelkerke R Square & 0.087 & & & 0.158 & & \\
\hline
\end{tabular}

Model 1 shows that sociodemographic indicators (gender, age, education level) and feeling of belonging to Spain have a moderate effect $\left(0.021>\mathrm{R}^{2}>0.13\right)$, following Cohen's criteria to value the effect size of the adjusted R2 (Cohen, 1988). As presented in Table 1 , individuals with higher educational levels show a higher support for Podemos. Nevertheless, the income level shows no significant effect ( $\mathrm{p}>$.05). Additionally, individuals expressing higher levels of feeling of belonging to Spain are less likely to support Podemos.

In the second Model, attitudinal variables related to immigration improve, significantly, the goodness of fit of the model ( $R 2=0.158)$. In sum, the following hypotheses are supported:

H1 (only partially): a higher vote for Podemos among those with higher educational levels $(b=0.210$; $\mathrm{p}=.000$ ), but no significant differences are observed that are linked to the household income level.

H2: a lower vote for Podemos among those believing that Public Health is negatively affected by migrants $(b=0.308 ; p=.002 ; b=0.776 ; p=.000)$.

H3: a lower vote for Podemos among those expressing preferentialist values $(b=-0.458$; $\mathrm{p}=.000)$.

H4: a lower vote for Podemos among women $(b=-$ $0.217 ; \mathrm{p}=.005)$.

H5: a lower vote for Podemos among those expressing assimilationist values. $(b=-0.273 ; p=.024)$.

H6: a lower vote for Podemos among those expressing anti-refugees attitudes $(b=-0.525 ; \mathrm{p}=.000)$.
H7: a lower vote for Podemos among those expressing higher levels of feeling of belonging to Spain $(b=-0.184 ; p=.000)$.

\section{Discussion}

These findings can be discussed in the light of previous theories. Firstly, the results presented above confirm that the Podemos's voters present antagonistic positions regarding the core values of nationalist populist parties. These results support the idea that Podemos populism presents an inclusive character (Mudde \& Rovira-Kaltwasser 2013), as opposed to nationalist preferentialism, such as Vox.

These results qualify previous arguments by showing that Podemos, despite adopting populist strategies, does not incorporate horizontal exclusionary elements (Brubaker, 2019), as is consistently the case with PRR. The data presented for the Spanish case contradict the existence of an intrinsic horizontal in/ out dimension of populism proposed by Brubake (2019, p. 13), referring to the exclusion of groups "at the margins (defined by culture, lifestyle, or gender/ sexual identity, not by wealth, power, etc.)" as well as "those on the bottom, represented also as different (ethnoracially, culturally or morally)".

These attitudes of the voters of Podemos are in line with the inclusive statements of their leaders -e.g. Pablo Iglesias declared, "those immigrant workers, nobody has the right to call you foreigners in Spain" (Iglesias, 2015, p. 184), underlining the vertical axis as 
fundamental and unique in its confrontational approach. In addition, the results show that Podemos voters show a lower level of feeling "Spanish" than the rest of the population. This data is in line with a political position of Podemos with respect to the Spanish nation: it is the only party operating nationwide that defends the Catalan self-determination referendum. Nor is here a horizontal exclusion with the minority national feelings present in Spain (e.g. Catalan, Basque, and Galician, among others).

All these results are in line with the theoretical distinction between populism and nationalism defended by De Cleen and Stavrakakis $(2017 ; 2020)$. These results do not exclude the existence of interactions between nationalism and populism in the case of Podemos, but they show the nationalist pulse in this party is lower than in general population in Spain -and, on certain issues, even showing an anti-nationalist character. This implies the necessity to analyze separately the nationalist character of populist parties (and vice versa), as proposed by these authors.

Also, the findings support some of the hypotheses raised by Custodi and Caiani (2019) pointing to a counterhegemonic character of the national discourse of Podemos. New debates should be addressed about the nature of nationalism and whether a party that does not mention the expression "We are a nation" or even reference "the Spanish nation" can still be considered as a nationalist party. In this regard, it can be argued that the new imagined community raised by Podemos cannot be labelled as nationalist without an electoral base expressing nationalist values or without references to the natural character of Spain or to the very same term of nation.

On the contrary, the use of the term patria that Podemos poses is denatured, built by the class struggle, as a space of rights and duties (Iglesias, 2015). In this sense, the patriotism of Podemos might be seen as a type of republican or constitutional patriotism (Lobera, 2019a)². As noted by García-Agustín (2018, p. 164), Podemos has offered an alternative to nationalism and to a populist reduction of the political community. Indeed, this party has advanced to "a republican populism in which patria is related to both the institutions and the people" (Íbid.).

Although the Podemos electorate is significantly less nationalist, preferentialist and assimilationist than the rest of the parties, this electorate is not homogeneous (as it is none). In this sense, a minority part of Podemos' voters present preferential and assimilationist attitudes. The additional evidence presented in Appendix 4 shows that individuals with lower levels of educational

Constitutional patriotism (Verfassungspatriotismus) is based on an identification of a reflexive nature not with particular contents of a particular cultural tradition, but with universal contents included in the normative order sanctioned by the constitution: human rights and the fundamental principles of the democratic rule of law (cf. Habermas 1989: 94). Republican patriotism is "explicitly particularistic" and grounded in "the citizens' passionate love of their republic's institutions and way of life" (Viroli, 2002, p. 14). attainment $(\mathrm{b}=.349 ; \mathrm{p}=.000)$ and higher levels of Spanishness $(b=.291 ; p=.000)$ might be more attracted by preferentialist discourses. Hence the need for a left-wing populist movement to strategically offer an alternative imagined community to the nation-based one to bring together left-wing voters.

The construction of a non-nationalist imagined community has a long tradition on the left. Arguably, this construction is even inseparable from the leftist movements themselves. Common expressions as "the people united will never be defeated" may reflect the need for unity within a collective that is strategically homogenized in the Marxist readings of society (e.g. Lukács, 2009 [1924]). Populist left-wing parties represent a working class without differences, as the 99\% against the "casta", the establishment (Jerez et al., 2015), constituting a "emancipatory" imagined community against the "natural" idea of nation used traditionally by the elites in order to divide the proletariat (Luxemburg, 1976 [1907]).

Since the Second International (1889-1916), the choice between an internationalist approach or the struggle within the existing nation-state structures has been conflicting on the left. Nevertheless, as Worth $(2019$, p. 1062) notes, most often "the nationstate remains the prime location for socialism to be built, through the premise of popular democracy and sovereignty". In the case of the new radical leftist parties, more research is needed to actualize this debate, since we can find rhetoric in both directions. In any case, it is doubtful that the election of a nationstate framework can be used as an indicator of leftwing nationalism.

De Cleen interestingly suggests analyzing whether the use of banal nationalism (Billig, 1995) can serve as an indicator of the nationalist character of leftist populism. This opens an interesting debate, since nationalism is so banalized that it daily permeates different levels of society. Arguably, banal nationalism would be a necessary but not sufficient condition to grant the status of nationalist to a political party; otherwise, one might find that all parties operating nationwide are nationalist, losing the analytical utility of this category.

The observations made by Custodi and Caiani (2019) about the use of the term patria by Podemos are very relevant. The results presented in this article partially confirm their conclusions about a counterhegemonic discourse in Podemos, although qualifying the nationalist category they use. The counterhegemonic (non-)nationalist and inclusive character of Podemos' populism can be further analyzed in the context of the electoral crystallization of the $15 \mathrm{M}$ protests that took place in Spain between 2011-2013 (see, for example, Sampedro \& Lobera, 2014; Lobera \& Rogero, 2017; Lobera, 2019b).

Generally, the termpatria hasbeen almostexclusively used by right-wing parties, particularly in Spain as a result of the country's long history of authoritarian nationalist rule. Podemos introduces a substantial change in the political culture of the Spanish left mentioning the word "Spain", as a patria, eliminating its character as a nation 
and replacing it with a type of constitutional patriotism focused on social conquests, in line with the social demands raised by the $15 \mathrm{M}$ movement. In this vein, the populist dimension of the use of patria is reflected in Podemos' idea "my patria is the people" (mi patria es la gente). This slogan was used by the party in social media, particularly during the Spanish national holiday in 2016, denouncing cuts in health, education, housing or dependency.

\section{Conclusions}

Can be the words "Spain" or "patria" be mentioned without a nationalist dimension by a populist party? In this article I discuss the results of the analysis of the values of the voters of Podemos in superdiverse areas. The analysis performed confirms that Podemos' inclusive discourse is reflected in the base of its electorate. Podemos' supporters are more likely to express inclusive attitudes towards ethnic diversity and immigration than the rest of voters.

In this article, I argued the condition of Podemos is an antagonistic political option to PRR positions. Spanish voters on the radical left and the radical right have incompatible beliefs about migrants, cultural diversity and feeling of belonging to Spain, and largely define themselves in opposition to one another.

As Lamont and Molnar (2002) stress, symbolic boundaries are not only employed to maintain social boundaries, but also to contest and reframe their meaning. In this vein, Podemos reframed the term Patria without horizontal symbolic boundaries, but with a critical vertical problematization, rivaling the ethnic nation as a producer of symbolic boundaries (e.g. Verdery, 1994). More research is desirable on how symbolic boundaries are drawn (both vertically and horizontally) across ideological spectrum, particularly among voters of radical right and radical left parties. This line of research can shed light on the ambiguous appeals to 'the people' in populist and nationalist discourses.
This study has several limitations that must be considered. The current political organization centered in the nation states implies a high degree of contextualization in the social construction of the meanings of the nation and country, particularly among the political left. Thus, the conclusions of this study should not be extrapolated to other countries, but integrated into a comparative discussion.

There is still a wide debate about the adaptation to Podemos of the different models of constitutional patriotism (Habermas, 1989; Fossum, 2001; Calhoun, 2002), critical or civic patriotism (Laborde, 2008), republican patriotism (Viroli, 2002) or republican populism (García-Agustín, 2018). Further analysis of the attitudes of its voters can contribute to this debate, in addition to the discursive analysis of its political elites. As noted by Barr (2018), consensusmaking is central for understanding what populism is. The present study is oriented from the analysis of the core values of the electoral bases of the party, around which consensus can be built. In this sense, a national survey will offer new perspectives to these conclusions and will be exploited in future articles to confirm or refute some of the conclusions presented here.

\section{Acknowledgments}

Thanks to Jacopo Custodi and Manuela Caiani for organizing the seminar "The Nation and the Radical Left - Practices and Discourses of National Identity in Left-Wing Politics", in the Centre on Social Movement Studies (Cosmos) at the Scuola Normale Superiore, Florence, the 28 and 29th of November 2019, where ideas on the central issues of this article could be discussed. Also, thanks to Benjamin De Cleen for his interesting keynote speech, and to my colleague Carlos de Castro for his insightful comments. An extensive thanks to all the participants in that seminar, to whose debate this article aims to contribute.

\section{References}

Barr, R.R. (2018). Populism as a political strategy. In Routledge Handbook of Global Populism (De la Torre C., pp. 4456). New York: Routledge.

Betz, H.G. (1993). The New Politics of Resentment: Radical Right-Wing Populist Parties in Western Europe. Comparative Politics, 25(4), 413-427. https://doi.org/10.2307/422034

Betz, H.G. (2017). Populism and islamophobia. In Political Populism (R.C. Heinisch, C. Holtz-Bacha, O. Mazzoleni, pp. 373-390). Nomos Verlagsgesellschaft mbH \& Co. KG.

Billig, M. (1995). Banal nationalism. London: Sage Publications.

Calhoun, C. J. (2002). Imagining Solidarity: Cosmopolitanism, Constitutional Patriotism, and the Public Sphere. Public Culture, 14 (1), 147-171. https://doi.org/10.1215/08992363-14-1-147

Custodi, J. \& Caiani, M. (2019). Nationalism and Populism on the Left: The Case of Podemos. Presented in the seminar "The Nation and the Radical Left - Practices and Discourses of National Identity in Left-Wing Politics", Florence (Italy), 28th of November 2019.

De Cleen, B. (2017). Populism and nationalism. In Oxford Handbook of Populism (Rovira Kaltwasser C. et al., pp. 342362). Oxford; New York: Oxford University Press. 
De Cleen, B., Moffitt, B., Panayotu, P. \& Stavrakakis, Y. (2019). The Potentials and Difficulties of Transnational Populism: The Case of the Democracy in Europe Movement 2025 (DiEM25). Political Studies, online first 10 May 2019. https:// doi.org/10.1177/0032321719847576

De Cleen, B. \& Stavrakakis, Y. (2017). Distinctions and articulations: a discourse theoretical framework for the study of populism and nationalism. Javnost - The Public, 24(4), 301-319.

De Cleen, B. \& Stavrakakis, Y. (2020). How should we analyze the connections between populism and nationalism: A response to Rogers Brubaker, Nations and Nationalism, online first, 1-9. https://doi.org/10.1111/nana.12575

De Orellana, P. \& Michelsen, N. (2019). Reactionary Internationalism: the philosophy of the New Right. Review of International Studies, 45(5), 748-767.

Duverger, M. (1955). The Political Role of Women. Paris: UNESCO.

Fossum, J. E. (2001). Deep diversity versus constitutional patriotism: Taylor, Habermas and the Canadian constitutional crisis. Ethnicities, 1(2), 179-206

García-Agustín, O. (2018). We the People or We the Republic? The Need for Republican Populism. In Podemos and the New Political Cycle (O. García-Agustín \& M. Briziarelli, pp. 147-169). London: Palgrave Macmillan.

Giménez, C., Lobera, J., Mora, T. \& Roche, D. (2015). Convivencia social e intercultural en territorios de alta diversidad. Encuesta 2015. Barcelona: Obra Social "La Caixa".

Iglesias, P. (2015). Una nueva transición: materiales del año del cambio. Madrid: Akal.

Inglehart, R. \& Norris, P. (2000). The Developmental Theory of the Gender Gap: Women and Men's Voting Behaviour in Global Perspective. International Political Science Review, 21(4), 441-62.

Inglehart, R. \& Norris, P. (2016). Trump. Brexit and the rise of Populism. Economic Have-nots and Cultural Backlash. Harvard Kennedy School Faculty Research Working Papers RWP 16-026, August.

Jerez, A., D’Antonio Maceiras, S. \& Maestu, E. (2015). Esferas públicas, crisis política e internet: el surgimiento electoral de Podemos. História, Ciências, Saúde-Manguinhos, 22, 1573-1596.

Laborde, C. (2008). Critical republicanism: the hijab controversy and political philosophy. Oxford University Press, Oxford.

Lamont, M. \& Molnár, V. (2002). The study of boundaries in the social sciences. Annual review of sociology, 28(1), 167195.

Lange, S. L. \& Mügge, L. M. (2015). 'Gender and right-wing populism in the Low Countries: ideological variations across parties and time’, Patterns of Prejudice, 49(1-2), 61-80. https://doi.org/10.1080/0031322x.2015.1014199

Lobera, J. (2015). From movements to political parties. The electoral crystallization of protest. Revista Española de Sociología, 24, 97-105.

Lobera, J. (2019a). Xenophobia, immigration and Podemos. Vote, competition and assimilationist cleavage in superdiverse areas in Spain. Presented in the seminar "The Nation and the Radical Left - Practices and Discourses of National Identity in Left-Wing Politics", Florence (Italy), 28th of November 2019.

Lobera, J. (2019b). Anti-austerity movements in Europe, in Routledge Handbook European Social Movements. Protest in Turbulent Times (C. Flesher Fominaya \& R. Feenstra, pp. 267-283). London: Routledge.

Lobera, J. \& Rogero, J. (2017). Measurement of the electoral crystallization of a social movement: from indignation to vote. Empiria, 38, 151-176. https://doi.org/10.5944/empiria.38.2018.19715

Lobera, J. \& Parejo, D (2019). Streets and institutions? The electoral extension of social movements and its tensions. In Routledge Handbook of Radical Politics (U. Gordon \& R. Kinna, pp. 314-325). London: Routledge.

Lukács, G. (2009). Lenin: A Study on the Unity of his Thought. Verso Books.

Luxemburg, R. (1976). The national question. New York, NY: Monthly Review.

March, L. (2012). Radical left parties in Europe. Routledge.

Mudde, C. \& Rovira Kaltwasser, C. (2017). Populism: A Very Short Introduction. New York: Oxford University Press.

Pogonyi, S. (2017). Extra-territorial ethnic politics, discourses and identities in Hungary. Springer.

Sampedro, V. \& Lobera, J. (2014). The Spanish 15-M movement: a consensual dissent? Journal of Spanish Cultural Studies. 15(1), 68-80. https://doi.org/10.1080/14636204.2014.938466

Sanahuja, J. A. (2016). Posglobalización y ascenso de la extrema derecha: crisis de hegemonía y riesgos sistémicos. Seguridad internacional y democracia: guerras, militarización y fronteras. Anuario 2017, 41-78.

Stavrakakis, Y., Katsambekis, G., Nikisianis, N., Kioupkiolis, A. \& Siomos, T. (2017). Extreme right-wing populism in Europe: revisiting a reified association. Critical Discourse Studies, 14(4), 420-439.

Spierings, N. \& Zaslove, A. (2017). Gender, populist attitudes, and voting: explaining the gender gap in voting for populist radical right and populist radical left parties. West European Politics, 40(4), 821-847. https://doi.org/10.108 0/01402382.2017.1287448

Swank, D. \& Betz, H.G. (2003). Globalization, the welfare state and right-wing populism in Western Europe. SocioEconomic Review, 1(2), 215-245. https://doi.org/10.1093/soceco/1.2.215

Taguieff, P. (1989). The doctrine of the national front in France(1972-1989): Arevolutionary programme? Ideological aspects of a national-populist mobilization. New Political Science, 8(1-2), 29-70. https://doi.org/10.1080/07393148908429620

Verdery K. (1994). Ethnicity, nationalism, and state-making. Ethnic Groups Boundaries: Past and Future. In The Anthropology of Ethnicity. Beyond "Ethnic Groups and Bounaries" (H. Vermeulen \& C. Govers, pp. 33-58). Amsterdam: Het Spinhuis. 
Viroli, M. (2002). Republicanism. New York: Hill \& Wang.

Wodak, R., KhosraviNik, M. \& Mral, B. (Eds.). (2013). Right-wing populism in Europe: Politics and discourse. A\&C Black.

Žižek, S. (2016). Against the Double Blackmail: Refugees, Terror and Other Troubles with the Neighbours. London: Penguin UK.

\section{Appendices}

Appendix 1. Source: our own production.

\begin{tabular}{|c|c|c|c|}
\hline Area & Region & Population & Interviews \\
\hline Blas Infante and Las Colombinas, Lepe (Huelva) & Andalusia & 26,931 & 326 \\
\hline Distrito Norte Polígono, Granada (Granada) & Andalusia & 25,867 & 341 \\
\hline Las Norias de Daza, El Ejido (Almería) & Andalusia & 9,206 & 283 \\
\hline Palma-Palmilla, Málaga (Málaga) & Andalusia & 30,767 & 390 \\
\hline Zona Sur, Jerez de la Frontera (Cádiz) & Andalusia & 32,679 & 350 \\
\hline Casco Histórico, Zaragoza (Zaragoza) & Aragon & 46,015 & 301 \\
\hline San Francisco and Zabala, Bilbao (Vizcaya) & Bask Country & 11,827 & 362 \\
\hline Playa Honda, San Bartolomé (Lanzarote, Las Palmas) & Canary Islands & 18,249 & 302 \\
\hline Teguise (Lanzarote, Las Palmas) & Canary Islands & 21,886 & 303 \\
\hline Daimiel (Ciudad Real) & Castile La Mancha & 18,176 & 322 \\
\hline Sigüenza (Guadalajara) & Castile La Mancha & 4,496 & 321 \\
\hline El Clot, Barcelona (Barcelona) & Catalonia & 27,039 & 314 \\
\hline El Raval de Ciutat Vella, Barcelona (Barcelona) & Catalonia & 47,608 & 285 \\
\hline $\begin{array}{l}\text { Les Roquetes, Trinitat Nova and Verdum, Barcelona } \\
\text { (Barcelona) }\end{array}$ & Catalonia & 37,926 & 317 \\
\hline Salt (Girona) & Catalonia & 29,836 & 265 \\
\hline Tortosa (Tarragona) & Catalonia & 33,445 & 302 \\
\hline Zona Nord de Nou Barris, Barcelona (Barcelona) & Catalonia & 10,342 & 312 \\
\hline Madre de Dios and San José, Logroño (La Rioja) & La Rioja & 38,441 & 299 \\
\hline Centro, San Nicasio, and Batallas, Leganés (Madrid) & Madrid & 32,923 & 338 \\
\hline Las Margaritas, Getafe (Madrid) & Madrid & 110,717 & 295 \\
\hline Lavapiés, Madrid (Madrid) & Madrid & 44,680 & 318 \\
\hline Pueblo Nuevo, Madrid (Madrid) & Madrid & 60,570 & 344 \\
\hline Carrús, Elche (Alicante) & Valencian Community & 33,702 & 660 \\
\hline La Coma, Paterna (Valencia) & Valencian Community & 9,301 & 326 \\
\hline Blas Infante and Las Colombinas, Lepe (Huelva) & Andalusia & 26,931 & 326 \\
\hline \multicolumn{2}{|l|}{ Total } & 662,629 & 7,976 \\
\hline
\end{tabular}


Appendix 2. Descriptive statistics of the independent variables. Source: our own production.

\begin{tabular}{|c|c|}
\hline Variable & Categories and Statistics \\
\hline \multicolumn{2}{|l|}{ Sociodemographics } \\
\hline Gender & $\begin{array}{l}0=\text { Men: } 49.6 \% \\
1=\text { Women: } 50.4 \%\end{array}$ \\
\hline Age & $\mathrm{M}=45.25, \mathrm{SD}=17.010$ \\
\hline Education level & $\begin{array}{l}\text { 1= Cannot read, illiterate: } 1.0 \% \\
2=\text { Without studies, he/she knows how to read: } 2.6 \% \\
3=\text { Incomplete Primary Education: } 6.2 \% \\
\text { 4= Primary education: } 14.5 \% \\
5=\text { Lower secondary education: } 29.6 \% \\
6=\text { Upper secondary education and Post-secondary non-tertiary: } 27.4 \% \\
7=\text { Short-cycle tertiary education: } 9.2 \% \\
8=\text { Bachelor degree or higher: } 9.5 \%\end{array}$ \\
\hline Household income level & $\begin{array}{l}\text { 1= Much higher (more than 2,200 Euros per month): } 4.5 \% \\
\text { 2= Higher: } 27.9 \% \\
3=\text { Around } 1,100 \text { Euros per month: } 28.8 \% \\
\text { 4= Lower: } 30.5 \% \\
\text { 5= Much lower (less than } 550 \text { per month): } 8.3 \%\end{array}$ \\
\hline \multicolumn{2}{|l|}{ Feeling of belonging } \\
\hline Feeling Spaniard & $\begin{array}{l}\text { 1= Not at all: } 7.4 \% \\
\text { 2=Very little: } 11.6 \% \\
\text { 3= Some: } 25.9 \% \\
\text { 4=A lot: } 54.3 \% \\
\text { DK/NA: } 0.8 \% \\
\end{array}$ \\
\hline \multicolumn{2}{|l|}{ Values and attitudes towards immigration } \\
\hline $\begin{array}{l}\text { Public Health negatively affected by } \\
\text { migrants }\end{array}$ & $\begin{array}{l}1=\text { Strongly or somewhat agrees: } 40.2 \% \\
2=\text { Somewhat disagrees: } 24.2 \% \\
3 \text { = Strongly disagrees } 24.4 \% \\
\text { DK/NA: } 11.3 \%\end{array}$ \\
\hline $\begin{array}{l}\text { Preferentialism } \\
\text { When hiring a person, it is preferred to hire a } \\
\text { Spaniard rather than an immigrant. }\end{array}$ & $\begin{array}{l}0=\text { Strongly or somewhat disagrees: } 48.5 \% \\
\text { 1= Strongly or somewhat agrees: } 47.1 \% \\
\text { DK/NA: } 4.4 \%\end{array}$ \\
\hline Refugees not welcome & $\begin{array}{l}0=\text { Accepts refugees to the country: } 48.0 \% \\
\text { 1= Rejects refugees coming to the country: } 44.1 \% \\
\text { DK/NA: } 7.9 \%\end{array}$ \\
\hline $\begin{array}{l}\text { Assimilationism } \\
\text { If immigrants want to stay here, they must } \\
\text { forget their customs, learn the language and } \\
\text { accept the customs of this country. }\end{array}$ & $\begin{array}{l}0=\text { pluralist values: } 82.1 \% \\
\text { 1= assimilationist values: } 17.9 \% \\
\text { DK/NA: } 2.2 \%\end{array}$ \\
\hline
\end{tabular}


Appendix 3. Values of the attitudinal variables among Podemos' supporters and the rest (1= Podemos' supporters). Source: our own production.

\subsection{Assimilationism}



\section{A3.3. Refugees not welcome}



A3.2. Feeling of belonging to Spain

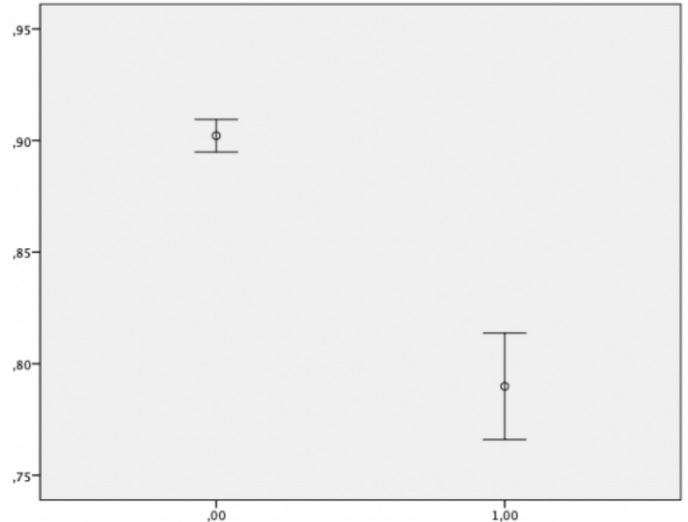

A3.4. Preferentialism

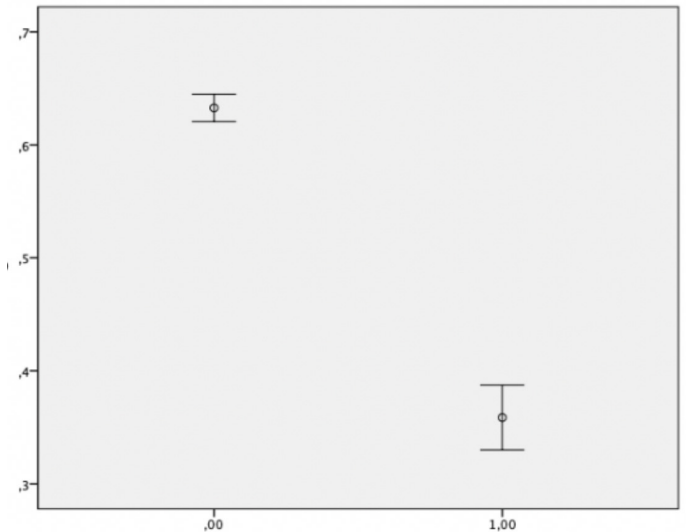

Note: T-tests show that the mean differences between the two groups are significant at a 0.01 level.

Appendix 4. Logit on preferentialism among Podemos' supporters. Source: our own production.

\begin{tabular}{|l|r|r|l|}
\hline $\mathrm{VD}=$ Preferentialism & \multicolumn{1}{|c|}{ B } & \multicolumn{1}{l|}{ S.E. } & Sig. \\
\hline Gender $(1=$ women $)$ & -0.069 & 0.129 & 0.594 \\
\hline Age & 0.008 & 0.005 & 0.094 \\
\hline Education level & -0.349 & 0.053 & 0.000 \\
\hline Household income level & 0.069 & 0.065 & 0.285 \\
\hline Feeling Spaniard & 0.291 & 0.072 & 0.000 \\
\hline Constant & -0.057 & 0.552 & 0.918 \\
\hline Nagelkerke R Square & 0.118 & & \\
\hline
\end{tabular}

